ENTREPRENEURSHIP AND SUSTAINABILITY ISSUES

ISSN 2345-0282 (online) http://jssidoi.org/jesi/ 2020 Volume 8 Number 1 (September)

http://doi.org/10.9770/jesi.2020.8.1(9)
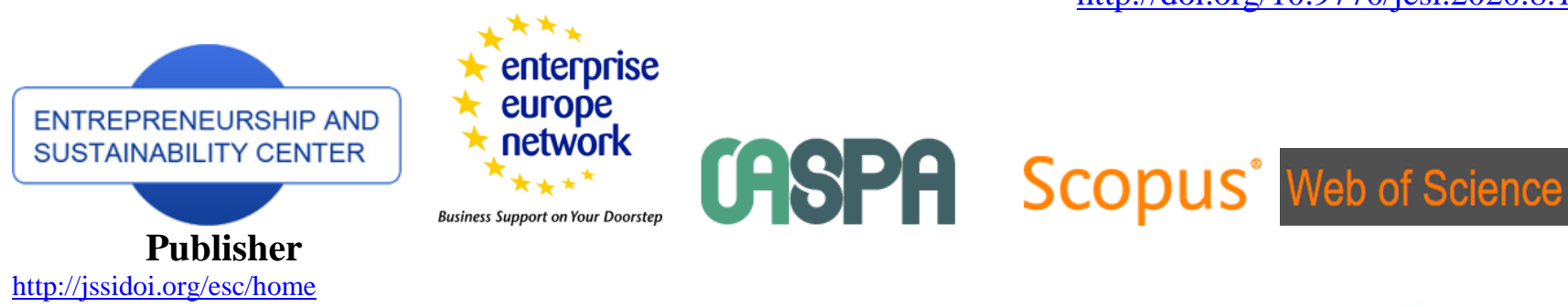

http://jssidoi.org/esc/home

\title{
DEVELOPMENT OF THE FINANCIAL POLICY OF THE EURASIAN ECONOMIC UNION COUNTRIES: TAX HARMONIZATION
}

\author{
Artem Krasnov ${ }^{1}$, Aizada Okanova ${ }^{2}$, Yana Yeraliyeva ${ }^{3}$, Maral Kozhakhmetova ${ }^{4}$, Alma Karshalova ${ }^{5}$, \\ Madina Aitkazina ${ }^{6}$ \\ ${ }^{1}$ Kyrgyz-Russian Slavic University, Kievskaya Street, 44, Bishkek, 720000, Kyrgyzstan \\ 2-6JSC “Narxoz University”, Zhandosova Street, 55, Almaty, 050035, Kazakhstan
}

Received 10 January 2020; accepted 15 June 2020; published 30 September 2020

\begin{abstract}
The paper presents an analysis of viewpoints in the debate concerning tax harmonization in integration unions and the results achieved in the Eurasian integration process, focusing on the specifics of taxation in the EAEU member states. The findings have led the author to conclude that there are considerable differences in taxation approaches and the rates of major budget-forming taxes and excises in the EAEU countries and non-tariff barriers still exist in product and services markets, which is an obstacle for mutual trade and access of excisable goods to the markets of union states. Measures to refine taxation systems are identified with a view to expanding budget revenues and ensuring the competitiveness and financial stability of the EAEU member states. Such measures include the establishment of a unified identification system for foreign trade operators (UISFTO), enhancement of electronic services, automation of information exchange between tax and customs authorities and implementation of new tax administration mechanisms in digital trade.
\end{abstract}

Keywords: indirect taxation; VAT; excises; customs duties; double taxation; personal income taxation; tax administration

Reference to this paper should be made as follows: Krasnov, A., Okanova, A., Yeraliyeva, Y., Kozhakhmetova, M., Karshalova, A., Luká, M.A. 2020. Development of the financial policy of the Eurasian economic union countries: tax harmonization. Entrepreneurship and Sustainability Issues, 8(1), 138-149. http://doi.org/10.9770/jesi.2020.8.1(9)

JEL Classifications: F30, F33

\section{Introduction}

The Eurasian Economic Union (EAEU) was established, in part, as a response to the economic and political influence of the European Union and other countries. Currently, the member states are Armenia, Belarus, Kazakhstan, Kyrgyzstan and Russia. The EAEU's key objectives are to raise the competitiveness and cooperation between the member states and to promote stable development in order to raise the living standards of the member states.

The EAEU provides for free movement of goods, services, capital and labor between the states and envisages coordinated and harmonized common policy in macroeconomics, transport, manufacturing and agriculture, energy, foreign trade and investment, customs, technical regulation, competition and antitrust regulation. 


\section{ENTREPRENEURSHIP AND SUSTAINABILITY ISSUES}

ISSN 2345-0282 (online) http://jssidoi.org/jesi/ 2020 Volume 8 Number 1 (September) http://doi.org/10.9770/jesi.2020.8.1(9)

Apart from the primary goals, such as facilitating conditions for stable development of the economies of the member states with a view to improving living standards for local populations and proceeding toward the establishment a single market in goods, services, capital and labor resources within the EAEU, another major objective of the Union is the development of a common tax area.

The issues of tax standardization and harmonization of tax legislation in the EAEU countries have gained specific relevance. The countries' emerging objectives are the refinement of tax administration mechanisms, elimination of disproportions and establishment of equal economic conditions in personal income taxation.

\section{Literature review}

One of the key areas of integration taking place in the Eurasian territory is the financial sector. The ultimate goal of integration in the financial sphere is the establishment of a common financial market of the EAEU member states (Kofner, 2018). An important direction in cooperation between the member states in the development of a common financial market is the harmonization of tax legislation (Paying Taxes 2019; 2018).

The economic influence of taxation systems for member countries of integration unions has been approached by researchers of various academic schools. A common view is that the transition to a "fiscal union" for members of integration unions has a stabilizing effect in the case of macroeconomic shocks (Bargain et al., 2013).

Liapis, Rovolis and Galanos (2013) point that tax burden on salary, profit, assets and goods and services has a significant impact on the competitiveness between countries, which, in turn, considerably influences the real economy of common markets.

Integration covers almost all aspects of relations in member states, particularly, politics, economics, social and cultural spheres (Dudin et al., 2019). The term "tax harmonization" is used to refer to this process (Safonova et al., 2016).

Tax harmonization is an important part of the process of financial integration. Fiscal integration is a process whereby a group of countries agrees on a set of measures to achieve a higher level of budget convergence, with the ultimate goal of establishing a fiscal union (Daniele and Geys, 2015).

Tax harmonization is usually deemed as a process of adjustment of tax systems across jurisdictions for the achievement of a common political goal (Bénassy-Quéréa et al., 2014). Tax harmonization involves the elimination of tax distortions affecting the flows of goods and production inputs to ensure efficient distribution of resources within the integrated market (Ponomareva et al., 2019; Wołowiec, 2018).

According to the German economist Sinn (1990), tax harmonization is the process, by which a heterogeneous group of countries, federal states or even local governments agree on setting a minimum and maximum level of their tax rates, including a higher degree of harmonization of tax legislation, in order to attract foreign investors and to encourage local development and investments.

The discussion of tax harmonization has been on for several years and no common ground has been found yet whether the policy should be maintained at the national level or coordinated in a wider international group (Ďurinová, 2006).

The need for tax harmonization in member states of integration unions is emphasized in the works by Baldwin (Baldwin and Wyplosz, 2012), Andriyash (2014) and Lucas (2001). 


\section{ENTREPRENEURSHIP AND SUSTAINABILITY ISSUES}

ISSN 2345-0282 (online) http://jssidoi.org/jesi/ 2020 Volume 8 Number 1 (September) http://doi.org/10.9770/jesi.2020.8.1(9)

Tax harmonization and coordination within integration unions help to stabilize revenues and avoid tax distortions and ensure smooth and uninterrupted operation of the common market with free movement of goods, services and capital (Liapis et al., 2016).

Tax legislation harmonization and the signing of international treaties allow avoiding double taxation (Himçi, 2014).

However, alternative views on the effects of a common fiscal policy on national economies uncovering the drawbacks of tax harmonization are presented in De Grauwe (2003), Rita de la Feria (2009), etc.

Tax harmonization involves three elements: the alignment of tax rates, common tax base determination approach and uniform application of agreed rules (Bräutigam, 2008).

Tax harmonization covers two directions, those of direct and indirect taxation (Beauvallet, 2018). Regarding direct tax harmonization, there are usually considerable differences between the tax systems of member states (Morina and Peci, 2017).

The harmonization of indirect taxes should involve convergence in statutory regulations governing VAT and excises (Teacher and Law, 2013).

Assessments of economic consequences of indirect tax harmonization in integration unions can be found in the works by Posen and van Walbeek (2014), Bouw (2017), Petrosyan (2016), Slintáková and Klazar (2010), Jenkins, Jenkins and Kuo (2006), Mathis (2004), Hodzic and Celebi (2017), Slintáková et al. (2010), etc.

A special focus of the EAEU agenda now is the harmonization of indirect taxes, as they directly influence the pricing in mutual trade (Likhacheva, 2018). Growing mutual trade turnover would increase budget revenues from indirect taxes (Saktaganova et al., 2018).

The provisions of articles 71 and 72 of Section XVII "Taxes and Taxation" of the Treaty on the Eurasian Economic Union set forth the principles of member states cooperation in the field of taxation and indirect tax collection in member states making the basis of the 18th Protocol to the EAEU Treaty (Protocol on the Procedure of Levying Indirect Taxes..., 2014).

The most noticeable achievements of the EAEU in simplifying the payment and calculation procedures of indirect taxes include (Tavadian, 2019):

- The collection of indirect taxes is carried out in accordance with the principle of the country of destination, which provides for the application of a zero rate of VAT on exports with the right to recover input VAT. Imports are subject to VAT, which is levied alongside other customs duties and taxes;

- Indirect taxes on imported goods should not exceed indirect taxes on similar domestic products (the principle of non-discrimination);

- $\quad$ Setting minimum rates in respect of excisable goods;

- $\quad$ Regulation of tax administration principles in indirect taxes.

As to the unification of direct taxation, the progress is currently extremely slow, as it takes the challenging path of compromise since direct taxes are closely tied to the national economy and social development.

An analysis of literature suggests that taxation is one of the areas vividly demonstrating that there is still a long way to go before full economic integration is achieved as it can only be accomplished with full tax harmonization. 


\section{ENTREPRENEURSHIP AND SUSTAINABILITY ISSUES}

ISSN 2345-0282 (online) http://jssidoi.org/jesi/ 2020 Volume 8 Number 1 (September) http://doi.org/10.9770/jesi.2020.8.1(9)

Even with numerous scientific publications concerning taxation, the aspects of tax harmonization in the EAEU integration space have not been adequately studied and require further research.

The aim of this paper is to develop forward-looking directions of cooperation within the EAEU in refining the tax collection system and developing a common tax area of the EAEU.

The harmonization of tax systems of the EAEU states is a principal step in integration, which is aimed at the elimination of administrative barriers in mutual trade and establishment of equal competitive conditions for economic entities in the EAEU area.

\section{Methods}

The methodological basis of the research is bibliometric analysis of literature, qualitative and quantitative analysis of documents and statistical data, as well as expert assessment of tax harmonization issues.

Several groups of sources were used for this research to ensure reliability and relevance of obtained information:

- Web of Science and Scopus publication databases containing peer-reviewed papers mostly in English from Russian and international scientific journals and allowing access not only to abstracts, but also full texts of papers, reviews, conference reports, etc.;

- Specialized resources for full-text search in research publications in all formats and disciplines (Scirus and Google Scholar, etc.);

- Official sources, including regulations of the EAEU concerning the development of the integration area, including bilateral treaties and memoranda;

- Analytical materials, reports, periodical reviews and studies of the Eurasian Development Bank, Eurasian Economic Commission, Eurasian Partnership;

- National information sources, including tax codes of the member states of the EAEU, and databases of statistical indicators concerning finance and budget revenues.

The empirical part of the study was based on the initial analysis of data characterizing tax system development in the EAEU member states and the results of quantitative studies as part of expert surveys engaging respondents with relevant competence levels and professional background in finance and taxation.

The expert survey was meant to identify the key challenges and administrative barriers and determine the outlook of cooperation in tax policy in the EAEU area.

The survey was primarily conducted in the form of a questionnaire filled in by a group of 10 respondents, including specialists of research organisations, tax practitioners and officials.

The experts were asked to assess a list of barriers for tax harmonization to identify the most urgent and significant points. For that, the ranking method was used; each problem was assigned a score of 1 to 5, where 1 indicated the lowest significance and 5 - the highest significance.

\section{Results}

Over the relatively short period of existence of the EAEU, remarkable progress has been achieved in Eurasian integration. One of the key aspects in expanding mutual trade, free movement of capital, financial resources, services and labor within the integration union is tax policy. 
In 2015-2017, tax revenues across all member countries of the integration union registered rising trends (Table 1).

Table 1. Tax revenues in fiscal revenues of member countries of the EAEU, billions of national currency.

\begin{tabular}{|l|r|r|r|r|r|}
\hline \multicolumn{1}{|c|}{ Country } & \multirow{2}{*}{2015} & \multirow{2}{*}{2016} & \multirow{2}{*}{2017} & \multicolumn{2}{c|}{ Change } \\
\cline { 4 - 6 } & & & \multicolumn{1}{c|}{+ - } & \multicolumn{1}{c|}{$\%$} \\
\hline Armenia, billion Armenian drams & $1,072.1$ & $1,090.9$ & $1,168.9$ & 96.8 & $9.0 \%$ \\
\hline Belarus, billion Belarusian rubles & 22.3 & 23.9 & 25.6 & 3.3 & $14.8 \%$ \\
\hline Kazakhstan, billion tenges & $5,551.2$ & $6,393.5$ & $7,518.7$ & $1,967.5$ & $35.4 \%$ \\
\hline Kyrgyzstan, billion soms & 84.7 & 93.8 & 103.4 & 18.7 & $22.1 \%$ \\
\hline Russia, billion Russian rubles & $15,421.4$ & $15,866.6$ & $17,617.9$ & $2,196.5$ & $14.2 \%$ \\
\hline
\end{tabular}

The major budget-forming tax for the EAEU countries is VAT (Fig. 1).

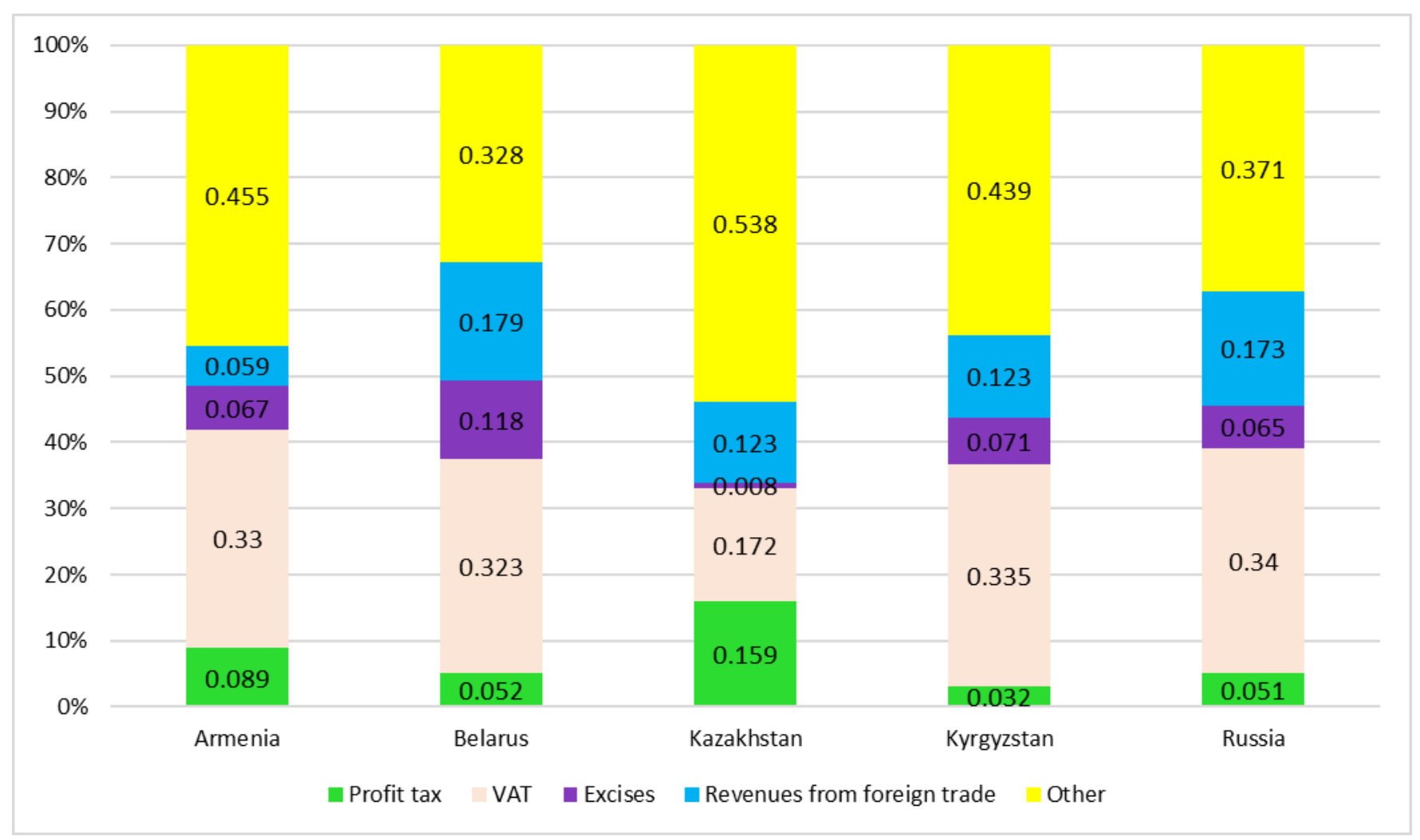

Fig. 1. Tax revenue structure in the EAEU member countries in 2017.

Source: Financial statistics of the Eurasian Economic Union, 2018.

It is worth noting that for now, there are still considerable differences in the VAT rates in the EAEU member countries (Table 2). 


\section{ENTREPRENEURSHIP AND SUSTAINABILITY ISSUES}

ISSN 2345-0282 (online) http://jssidoi.org/jesi/ 2020 Volume 8 Number 1 (September) http://doi.org/10.9770/jesi.2020.8.1(9)

Table 2. Rates of major taxes in the EAEU member countries in 2018.

\begin{tabular}{|c|c|c|c|c|c|}
\hline \multirow[b]{2}{*}{ Country } & \multicolumn{2}{|c|}{ VAT } & \multirow[b]{2}{*}{ Profit tax } & \multirow[b]{2}{*}{ Personal income tax } & \multirow[b]{2}{*}{ Corporate property tax } \\
\hline & Standard rate & $\begin{array}{r}\text { Discounted } \\
\text { rate }\end{array}$ & & & \\
\hline Armenia & $20 \%$ & $0 \%$ & $5 \% ; 10 \%$ & $10 \% ; 20 \%$ & from $0.1 \%$ to $0.8 \%$ \\
\hline Belarus & $20 \%$ & $0 \% ; 10 \%$ & $10 \% ; 12 \% ; 18 ;$ & $4 \% ; 9 \% ; 12 \% ; 15 \%$ & $1 \%$ \\
\hline Kazakhstan & $12 \%$ & $0 \%$ & $10 \% ; 15 \% ; 30 \%$ & $5 \% ; 10 \%$ & $0.5 \% ; 1.5 \%$ \\
\hline Kyrgyzstan & $12 \%$ & $0 \%$ & $0 \% ; 5 \% ; 10 \%$ & $10 \%$ & $0.35 \% ; 0.5 \% ; 0.8 \%$ \\
\hline
\end{tabular}

In 2018, the VAT rate in Belarus and Armenia equaled 20\%. The lowest rates (12\%) were in Kazakhstan and Kyrgyzstan. A discounted rate of $10 \%$ is applied in Russia and Belarus (OECD, 2018). Starting January 1, 2019, a law came into effect in Russia, raising the VAT rate to $20 \%$ from $18 \%$. Simultaneously, under the act, all applicable discounted rates of the tax set at $10 \%$ are still in place.

Personal income taxes in the EAEU states are levied in accordance with article 73 of the Treaty on the EAEU at the rates applicable for residents of the state where such citizen of an EAEU state is employed. Different rates are applied in personal income taxes. The personal income tax rates for residents of the EAEU states range from 4\% to $35 \%$. The lowest base rate of the personal income tax is established in Kazakhstan and Kyrgyzstan. The most differentiated personal income tax scale among the EAEU states is used in the Russian Federation (the minimum level is $9 \%$, the maximum level is $35 \%$ ).

As to excises, similar excisable product categories are established in the EAEU countries. The alignment of excisable product categories to a common framework list was performed as part of the unification and harmonization of taxation of the member states of the EAEU (Iakunina, 2017).

The trends of excise rates in the EAEU countries in 2015-2017 are shown in Table 3.

Table 3. Trends of excise rates in the EAEU member states in 2015-2017.

\begin{tabular}{|l|l|l|l|}
\hline \multicolumn{1}{|c|}{ Country } & \multicolumn{1}{|c|}{2015} & \multicolumn{1}{c|}{2016} & \multicolumn{1}{c|}{2017} \\
\hline $\begin{array}{l}\text { Russia } \\
\text { (cigarettes) }\end{array}$ & $\begin{array}{l}960 \text { rubles per 1,000 pieces }+ \\
9 \%, \text { but not less than 1,250 } \\
\text { rubles per 1,000 pieces }\end{array}$ & $\begin{array}{l}1,250 \text { rubles per 1,000 pieces }+ \\
8.5 \%, \text { but not less than 1,040 } \\
\text { rubles per 1,000 pieces }\end{array}$ & $\begin{array}{l}1,420 \text { rubles per 1,000 } \\
\text { pieces }+9.5 \%, \text { but not } \\
\text { less than } 1,600 \text { rubles per } \\
1,000 \text { pieces }\end{array}$ \\
\hline $\begin{array}{l}\text { Belarus } \\
\text { (smoking tobacco, pipe tobacco) }\end{array}$ & $\begin{array}{l}386,300 \text { Belarusian rubles per } \\
1 \text { kilogram }\end{array}$ & $\begin{array}{l}482,700 \text { Belarusian rubles per 1 } \\
\text { kilogram }\end{array}$ & $\begin{array}{l}386,300 \text { Belarusian rubles } \\
\text { per 1 kilogram }\end{array}$ \\
\hline $\begin{array}{l}\text { Kazakhstan } \\
\text { (filter tip cigarettes) }\end{array}$ & 3,900 tenges per 1,000 pieces & 5,000 tenges per 1,000 pieces & pieces \\
\hline $\begin{array}{l}\text { Armenia } \\
\text { (filter tip tobacco cigarettes) }\end{array}$ & 5,000 drams per 1,000 pieces & 5,000 drams per 1,000 pieces & $\begin{array}{l}5,000 \text { drams per 1,000 } \\
\text { pieces }\end{array}$ \\
\hline $\begin{array}{l}\text { Kyrgyzstan } \\
\text { (filter tip cigarettes) }\end{array}$ & $\begin{array}{l}350 \text { soms per 1,000 pieces }+ \\
8 \%, \text { but not less than 450 } \\
\text { soms per 1,000 pieces }\end{array}$ & 580 soms per 1,000 pieces & $\begin{array}{l}1,000 \text { soms per 1,000 } \\
\text { pieces }\end{array}$ \\
\hline
\end{tabular}

According to the results of the expert ranking, the top three barriers hindering integration processes in the EAEU area are as follows (Fig. 2):

- $\quad$ wide-ranging tax reliefs at the national level;

- considerable differences in indirect tax rates established at the national level make the most crucial problem;

- $\quad$ inadequacy of interdepartmental cooperation between customs and tax authorities. 


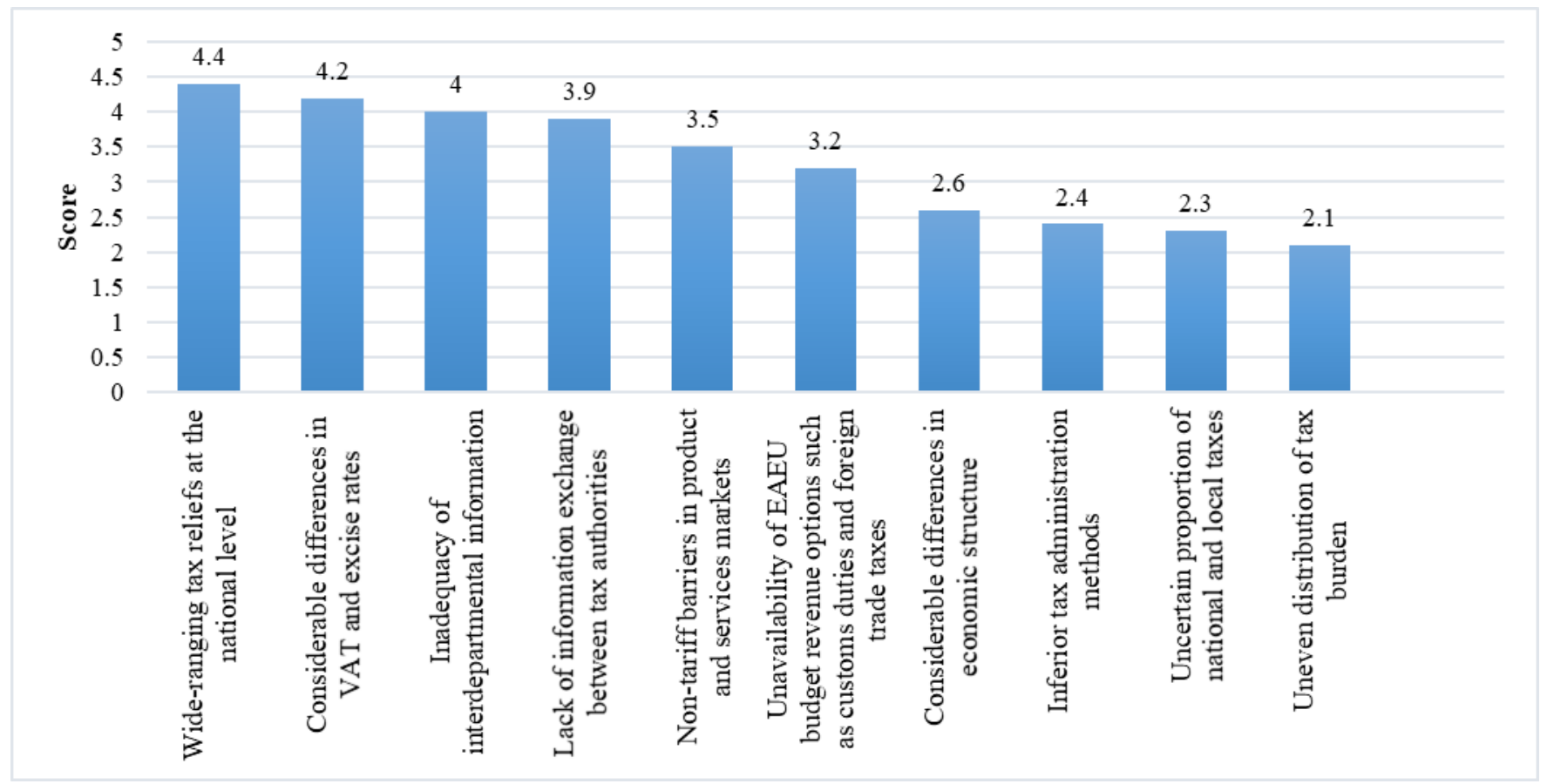

Fig. 2. Expert assessments of tax barriers in the EAEU area.

According to the experts, the most acute problem is that of tax reliefs at the national level. E.g., a discounted VAT rate applies in the Republic of Belarus for several domestically manufactured product types.

Considerable differences in taxation approaches with regard to indirect tax rates in the EAEU countries constitute the second most significant problem and a barrier in mutual market access for excisable products between the member states, which creates the basis for their uncontrolled cross-border flows and expansion of shadow sectors.

Moreover, the experts cite the issues of information exchange between tax authorities in the EAEU, such as remaining non-tariff barriers in product and services markets and unavailability of EAEU budget revenue options such as customs duties and foreign trade taxes (excises, VAT).

However, several challenges are now slowing down the integration process in the union, particularly, considerable differences in taxation approaches in the EAEU countries, remaining non-tariff barriers in product and services markets and unavailability of EAEU budget revenue options, such as customs duties and foreign trade taxes (excises, VAT).

\section{Discussion}

The EAEU countries' objectives now include the refinement of the indirect taxation collection system and further harmonization of tax legislation, elimination of disproportions and establishment of equal economic conditions in taxation (Dorski et al., 2017; Bulkhairova et al., 2019). 


\section{ENTREPRENEURSHIP AND SUSTAINABILITY ISSUES}

ISSN 2345-0282 (online) http://jssidoi.org/jesi/ 2020 Volume 8 Number 1 (September) http://doi.org/10.9770/jesi.2020.8.1(9)

The experts were asked to propose priority directions in tax harmonization efforts within the integration union of the EAEU. According to the experts, such priorities include:

- $\quad$ Establishment of an identification system for foreign trade operators within the EAEU;

- $\quad$ Enhancement of online services of tax authorities and arrangement of automated information exchange;

- $\quad$ Refinement of tax administration mechanisms in electronic commerce and excisable product market.

The need for an identification system for foreign trade operators reflects the fact that the existing registration systems for individuals and legal entities operated in the EAEU countries are completely different. Thus, a Taxpayer Identification Number is assigned in the Republic of Armenia, a Payer's Identification Number - in the Republic of Belarus, an Individual Identification Number/Business Identification Number - in the Republic of Kazakhstan, a Taxpayer's Identification Number and a Code of Republican Classifier of Enterprises and Organizations - in the Kyrgyz Republic and a Taxpayer Identification Number - in the Russian Federation.

Besides, any single foreign trade operator may be simultaneously registered under different identification numbers, which in some cases renders unique identification of the operator almost impossible.

According to one of the experts, an established identification system for foreign trade operators within the EAEU would be instrumental in "optimizing the volume of processed information and in simplifying electronic information exchange between tax and customs authorities" (Expert B, head of information systems integration department, more than 10 years expertise).

All EAEU members support the UISFTO initiative, though with their own specific concepts and propositions. In particular, the State Customs Committee of Belarus proposes that the system should serve the goals of customs regulation, as well as state tax regulation within the EAEU area (Bakinova et al., 2019).

Another priority for the EAEU is the enhancement of online services of tax authorities and establishment of automated information exchange in the EAEU countries (Frolova et al., 2018). The lack of efficient mechanisms of cooperation and information exchange between tax authorities in the EAEU increases the risk of tax evasion among residents (Novikov et al., 2019). According to OECD estimates, budget revenue losses associated with tax base erosion reach USD 100-240 billion per year, which corresponds to 4-10\% of the global corporate income tax.

The lack of efficient mechanisms of cooperation and information exchange between tax authorities in the EAEU poses the risk of intensifying tax competition and tax evasion among residents.

According to A. Levashenko, Head of the Russia-OECD Center, fighting tax evasion requires that the Treaty on the Eurasian Economic Union should include the objective of promoting cooperation in information exchange between tax authorities and an action plan should be developed under the OECD standards to counter tax-related malpractices (Levashenko, n. d.). Such plan should set tasks regarding the development of automated information exchange in a wide scope of tax issues and the accession of countries to the automated information exchange system under multilateral CRS MCAA and CbC MCAA frameworks (Malikova et al., 2019).

The need for enhancement of the mechanisms of tax administration is caused by globalization and informatization of economic processes (Onokoy et al., 2019). The main challenges in taxation in the EAEU countries remain the cross-border online trade and electronic service provision, while the respective tax arrangements are still under development. Particularly, one of the objectives of tax policy in the EAEU is the development of conceptual goals of taxation in electronic commerce (Perepelitsa et al., 2018). 


\section{ENTREPRENEURSHIP AND SUSTAINABILITY ISSUES}

ISSN 2345-0282 (online) http://jssidoi.org/jesi/ 2020 Volume 8 Number 1 (September) http://doi.org/10.9770/jesi.2020.8.1(9)

The experts' key focus, for now, relates to the following two blocks of issues, namely the development of a VAT collection mechanism for electronic services and analysis of taxation methods for cross-border trade in goods.

The mechanism of taxation of electronic services is based on the practice of the European Union and the provisions of Russian and Belarusian laws in the field, as relevant tax regulations are in place in these member states.

The aspects of indirect taxation of electronic commerce on the Internet are not specifically governed in the legislation of the member states and general rules apply to indirect taxation of imports and sales (Dyussembekova et al., 2019). For now, only Kazakhstan has specific regulation mechanisms in place with regard to corporate income tax in electronic commerce. Since 2018, the notions of "online marketplace", "online store" and "ecommerce" have been set forth in the Tax Code of the Republic of Kazakhstan.

The experts note that, in all areas of the digital transformation of the EAEU member states, a key priority is the development of a statutory terminological framework of electronic commerce at the Union level, which would prevent collisions and conflicts in legal regulation. The proposal needs to be discussed regarding the introduction of the term "electronic services" in Treaty on the Eurasian Economic Union and the establishment of a concerted mechanism of VAT levying in electronic service provision, exceptions and the procedure for determining the place of supply of such services.

Thus, the proposed directions of cooperation within the EAEU would promote convergence between the tax systems and the development of a common tax area of the EAEU.

\section{Conclusion}

The conducted research confirmed the assumption that tax harmonization should be viewed as a crucial stage of the integration process, intended to bring down barriers and create equal competitive conditions in mutual trade for economic entities in the EAEU member states.

The development of a common financial market is impossible without the refinement of the taxation systems of the EAEU member states. Tax harmonization and convergence efforts are currently underway in the Union.

However, the remaining obstacles, such as considerable differences in taxation approaches, and unavailability of budget revenue options, such as customs duties and foreign trade taxes, have hindered integration processes and the development of mutual trade in the EAEU member states.

Priority directions of taxation system development in the EAEU countries relate to the establishment of an identification system for foreign trade operators, enhancement of online services and automation of information exchange between tax and customs authorities and implementation of new mechanisms of tax administration in digital commerce.

The findings of the conducted research suggest certain challenges are still weighing over the tax harmonization process, which warrants further research regarding the enhancement of tax administration, non-tariff regulation, etc. 


\section{ENTREPRENEURSHIP AND SUSTAINABILITY ISSUES}

ISSN 2345-0282 (online) http://jssidoi.org/jesi/ 2020 Volume 8 Number 1 (September) http://doi.org/10.9770/jesi.2020.8.1(9)

\section{References}

Andriyash, M.M. 2014. Problems of taxation of the value added tax of the EU membership. Actual Problems of International Relations 122(1): 215-227.

Bacache Beauvallet, M. 2018. Tax competition, tax coordination, and e-commerce. Journal of Public Economic Theory 20(1): $100-117$. https://doi.org/10.1111/jpet.12254

Bakinova, T.; Darbakova, N.; Kazakova, G.; Sangadzhieva, S.; \& Darbakova, I. 2019. Information Support of Monitoring as a Tool of Ecological Optimization of Agricultural Land Use. Journal of Environmental Management and Tourism 10(1), $195-201$.

Baldwin, R.; \& Wyplosz, Ch. 2012. The Economics of European Integration. New York: McGraw-Hill Education.

Bargain, O.; Dolls, M.; Fuest, C.; Neumann, D.; Peichl, A.; Pestel, N.; \& Siegloch, S. 2013. Fiscal union in Europe? Redistributive and stabilizing effects of a European tax-benefit system and fiscal equalization mechanism. Economic Policy 28(75): 375-422

Bénassy-Quéréa, A.; Trannoyb, A.; \& Wolffc, G. 2014. Tax Harmonization in Europe: Moving Forward. Les notes du conseil d'analyse économique. Les notes du conseil d'analyse économique 14. Retrieved from http://www.cae-eco.fr/IMG/pdf/cae-note014-en.pdf

Bouw, A. 2017. Tobacco Taxation in the European Union: An Overview. World Bank, Washington, DC. Retrieved from https://openknowledge.worldbank.org/handle/10986/26496

Bräutigam, D.A.; Fjeldstad, O.-H.; \& Moore, M. 2008. Taxation and State-Building in Developing Countries: Capacity and Consent. Cambridge University Press.

Bulkhairova, Z.S.; Saimagambetova, G.A.; Kizimbayeva, A.; Kadyrova, G.M.; \& Abdiyeva, S.R. 2019. The Situationof Food Security in Kazakhstan. Space and Culture, India 7(1): 194-205.

Daniele, G.; \& Geys, B. 2015. Public support for European fiscal integration in times of crisis. Journal of European Public Policy 22(5): $650-670$.

De Grauwe, P. 2003. Economics of Monetary Union. Oxford: Oxford University Press.

De la Feria, R. 2009. VAT and the EC Internal Market: The Shortcomings of Harmonisation. Working Papers 0929, Oxford University Centre for Business Taxation. Retrieved from https://ideas.repec.org/p/btx/wpaper/0929.html

Dorski, A.; Pavlenko, E.; Shutikova, N.; Zubanova, S.; \& Pashentsev, D. 2017. Advertisement in the EAEU Countries: Law Harmonization Issues. Journal of Advanced Research in Law and Economics 8(7), 2112-2120.

Dudin, M.N.; Pogrebinskaya, E.A.; Sidorenko, V.N.; Sukhova, E.I.; Zubenko N.Y.; \& Shishalova, J.S. 2019. Cross-cultural management in the system of harmonization of interests in the multi-confessional educational environment. European Journal of Science and Theology 15(3): 191-200.

Ďrinová, I. 2006. Taxation under conditions of economic globalization. National economy issues. BIATEC XIV(10): 18-21.

Dyussembekova, G.; Reshina, G.; Primbetova, S.; Sultanovaĩ, M.; \& Beisembayeva, G. 2019. Role and Importance of the Damu Enterprise Development Fund and International Investment Funds in Implementing Project and Leasing Financing Programs in Kazakhstan. Space and Culture, India 6(5): 156-165.

Financial statistics of the Eurasian Economic Union. Intelligence for 2017. Statistical book; Eurasian Economic Commission. 2018. Moscow.

Retrieved

from http://www.eurasiancommission.org/ru/act/integr i makroec/dep stat/fin stat/statistical publications/Documents/finstat/finstat $\underline{2017 . p d f}$

Frolova, E.; Polyakova, T.; Dudin, M.; Rusakova, E.; \& Kucherenko, P. 2018. Information Security of Russia in the Digital Economy: The Economic and Legal Aspects. Journal of Advanced Research in Law And Economics 9(1), 89-95.

Himçi, B. 2014. Avoidance of double taxation based on OECD agreements: Analyze of the Albanian-Italian model. Mediterranean Journal of Social Sciences 5(7): 218-223. 


\section{ENTREPRENEURSHIP AND SUSTAINABILITY ISSUES}

ISSN 2345-0282 (online) http://jssidoi.org/jesi/ 2020 Volume 8 Number 1 (September) http://doi.org/10.9770/jesi.2020.8.1(9)

Hodzic, S.; \& Celebi, H. 2017. Value-added tax and its effectiveness: EU-28 and Turkey. UTMS Journal of Economics 8(2): 79-90.

Jenkins, G.P.; Jenkins, H.P.; \& Kuo, C.Y. 2006. Is the Value Added Tax Naturally Progressive?" Retrieved from http://papers.ssrn.com/sol3/papers.cfm?abstract_id=897677

Kofner, Y. 2018. Towards the common financial market of the EAEU. Prospects of Eurasia. Quarterly Annex to the Eurasian Panorama. July 2018. No. 1. Moscow: Higher School of Economics. 28 p.

Levashenko, A. Novye standarty dlya obmena nalogovoi informatsiei v EAES [New standards for tax information exchange in the EAEU]. RANEPA. Russian Center for Competences and Analysis of OECD Standards. Retrieved from https://www.ranepa.ru/images/News/2017-04/doklady/oecd/levashenko.pdf

Liapis, K.; Rovolis, A.; \& Galanos, C. 2012. Toward a common tax regime for the European Union countries. European Research Studies Journal 15(3): 89-108.

Liapis, K.; Rovolis, A.; \& Galanos, C. 2013. Toward a common tax regime for the European Union countries. European Research Studies Journal 16(3): 93-116.

Likhacheva, A. 2018. The Eurasian Economic Union and the Integration Process in the Asia Pacific. Asian Politics and Policy 10(4): 772790.

Lucas, V. 2001. Tax harmonization and the principle of origin. Economic Letters 71(1): 111-115.

Malikova, I.I.; Gorelov, D.V.; Plotnikov, V.V.; Danilina, E.I. 2019. Creating a Municipal Information System of a City using GIS Technology. International Journal of Engineering and Advanced Technology 8(5): 430-434. https://www.ijeat.org/wpcontent/uploads/papers/v8i5/D6384048419.pdf

Mathis, A. 2004. Taxation Papers. VAT Indicators. Working Paper No. $2 . \quad$ Retrieved from http://ec.europa.eu/taxation_customs/resources/documents/vat_indicators.pdf

Morina, F.G.; \& Peci, B. 2017. The Concept of the Common Market: Advantages and Disadvantages in the Spectre of Harmonization the Tax System and the Benefits for Kosovo. Euro Economica 2(36): 55-61.

Novikov, A.V.; Saydulaev, D.D.; \& Kremcheeva, D.A. 2019. Service Sector and Information Technologies: Development of New Opportunities. International Journal of Innovative Technology and Exploring Engineering 8(9): 1389-1394.

OECD. 2018. Consumption Tax Trends 2018. VAT/GST and Excise Rates, Trends and Policy Issues. Consumption Tax Trends, Paris, OECD Publishing. Retrieved from https://read.oecd-ilibrary.org/taxation/consumption-tax-trends-2018_ctt-2018-en\#page198

Onokoy, L.S.; Kalabukhova, G.V.; Sorokin, A.A.; Polovnikova, A.V.; \& Babushkina, S.V. 2019. Prospects of The Development of Information Technologies in The Business Environment. International Journal of Recent Technology and Engineering 8(1): 8185 .

Paying Taxes 2019. Fourteen years of data and analysis of tax systems in 190 economies: how is technology affecting tax administration and policy? 2018. World Bank Group. Retrieved from https://www.pwc.com/gx/en/paying-taxes/pdf/pwc-paying-taxes-2019.pdf

Perepelitsa, D.G.; Khominich, I.P.; Semenkova, E.V.; Kachalova, E.S.; \& Ayyubov, Z.V. 2018. Issues in and Prospects for the Formation of the EAEU's Common Financial Market and Its Infrastructure. Espacios 39(41): 34. Retrieved from http://www.revistaespacios.com/a18v39n41/18394134.html

Petrosyan, H. 2016. Possible Ways of Further Evolution of Tax Systems in the EAEU Countries. Economic Policy, Russian Presidential Academy of National Economy and Public Administration 11(6): 222-241.

Ponomareva, N.V.; Zvereva, A.O.; Golubtsova, E.V.; \& Ilyashenko, S.B. 2019. Tax incentives for use of alternative energy sources in the Russian Federation. International Journal of Energy Economics and Policy 9(4): 144-148.

Posen, J.; van Walbeek, C. 2014. The Impact of Cigarette Excise Tax Increases and Harmonisation in the East African Community. SALDRU Working Papers 130. Cape Town, South Africa. 


\section{ENTREPRENEURSHIP AND SUSTAINABILITY ISSUES}

ISSN 2345-0282 (online) http://jssidoi.org/jesi/ 2020 Volume 8 Number 1 (September) http://doi.org/10.9770/jesi.2020.8.1(9)

Safonova, M.F.; Reznichenko, D.S.; Melnichuk, M.V.; Karaev, A.K.; \& Litvinova, S.F. 2016. Taxes harmonization features in the European union countries. International Journal of Economics and Financial 6((8)Special Issue): 154-159.

Saktaganova, G.; Legostaeva, L.; \& Karipova, A. 2018. Major Development Mechanisms for the Infrastructure of the Transport and Logistics Complex in Kazakhstan. Journal of Advanced Research in Law and Economics 9(4): 1474-1480.

Slintáková, B; \& Klazar S. 2010. Impact of Harmonisation on Distribution of VAT in the Czech Republic. Prague Economic Papers 2: 133-149.

Sinn, H.-W. 1990. Tax harmonization and tax competition in Europe. European Economic Review 34: 489-504

Tavadian, A. L. 2019 Zakonodatelstvo EAES o naloge na dobavlennuyu stoimost [EAEU legislation on value-added tax], in:

Research forum: Legal studies, history, sociology, political science and philosophy: collection of proceedings papers of the 26th international research and practical conference 2(26). Moscow: Izdatelstvo "MTsNO" [Publishing house "MTsNO"], 44-48.

Teacher, Law. November 2013. Tax Harmonisation in the European Union. Retrieved from https://www.lawteacher.net/free-lawessays/european-law/tax-harmonisation-in-the-european-law-essays.php?vref=1

Iakunina, K. D. 2017. Opyt primeneniya aktsiza v ramkakh EAES [Practice of excise levying in the EAEU], in: Research forum: Economics and management: collection of proceedings papers of the 11th international research and practical conference. 9(11). Moscow: Izdatelstvo "MTsNO" [Publishing house "MTsNO"], 69-74.

Wołowiec, T. 2018. Potential and Possible Ways of Harmonizing the Personal Income Taxation Process. Comparative Economic Research 21(3): 109-130.

Artem KRASNOV

ORCID ID: orcid.org/0000-0002-6564-8911

Aizada OKANOVA

ORCID ID: orcid.org/0000-0001-7612-2803

Yana YERALIYEVA

ORCID ID: orcid.org/0000-0002-2318-5920

Maral KOZHAKHMETOVA

ORCID ID: orcid.org/0000-0001-7445-787X

Alma KARSHALOVA

ORCID ID: orcid.org/0000-0002-0065-8369

Madina AITKAZINA

ORCID ID: orcid.org/0000-0002-8410-0900

ORCID ID: orcid.org/0000-0001-9587-5026

Copyright (C 2020 by author(s) and VsI Entrepreneurship and Sustainability Center

This work is licensed under the Creative Commons Attribution International License (CC BY).

http://creativecommons.org/licenses/by/4.0/

(c) (i) Open Access

